I'm mismatch, but I'm well-being

EMPLOYEE WELL-BEING, JOB CRAFTING, DAN PSYCHOLOGICAL EMPOWERMENT

Masalah education mismatch menjadi lumrah di bidang ketenagakerjaan khususnya di Indonesia. Edncation mismatch sendiri, sebenarnya dibedakan meniadi dua. horizontal clucution mismuat ch dan vertical edncution mismatch, dalam pembahasan ini hanya berfokus pada horizontal cdiccation mismatch, yaitu ketidakesesuaian antara lipe pendidikan yang dimiliki dan pekerjaan yang ditekuni sekarang. Dengan keadaan seperti ini, menjadikan karyawan yang mengalami horizontal education mismatch mau lidak mau harus mengeluarkan usalua yang lebih dari karyawan biasanya terhadap pekerjaan yang dilakukan. mereka dituntut untuk mempelajari lial-hal yang tidak menjadi suatu kebiasaan sebelumnya, mulai dari kompetensi. kemampuan. keterampilan, budaya, dan hal laimnya di tempat kerja yang sekarang.

Pastinya akan ada dampak yang terjadi ketika seorang karyawan memilih bekerja tidak sesuai dengan bidang pendidikan yang diambil. Mismaich yang terjadi di kalangan ketenagakerjaan ini akan berdampak pada tingkat kepuasan kerja karyawan yang meniadi rendah, meningkatnya mrnover di dalam perusahaan, serta turut menyebabkan pendapatan rendah pada karyawan tersebut. Lebih jauh lagi, hal ini akan berdampak pada karyawan yang dapat mengalami stres kerja. ini dapat teriadi dikarenakan karyawain tersebut pastinya akan menghadapi hal-hal yang berbeda dari sebelumnya serta tuntutan yang belum pernah dirasakan atau menjadi pengalanan pertama dalam laal ini. Beban karyawan dalam menyesuaikan tral tersebutlah yang kemudian menjadi potensi menyebabkan liertambahı buruknya keselıatan, peforma kerja. dan kesejahtitraan karyawam atau diselout juga cmployecrell-being.

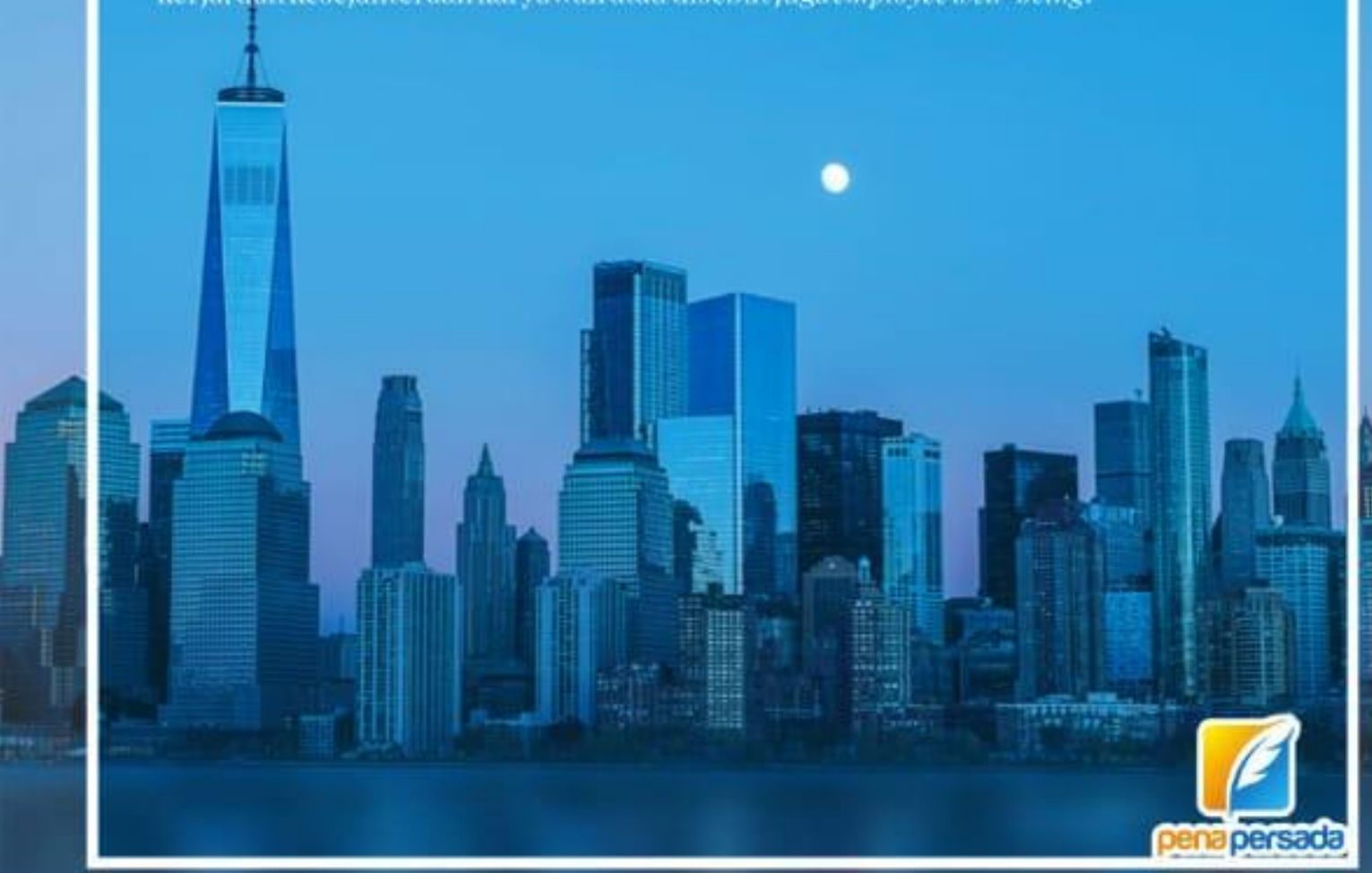

\section{I'm Mismatch,} but I'm well-being

EMPLOYEE WELL-BEING, JOB CRAFTING, DAN PSYCHOLOGICAL EMPOWERMENT

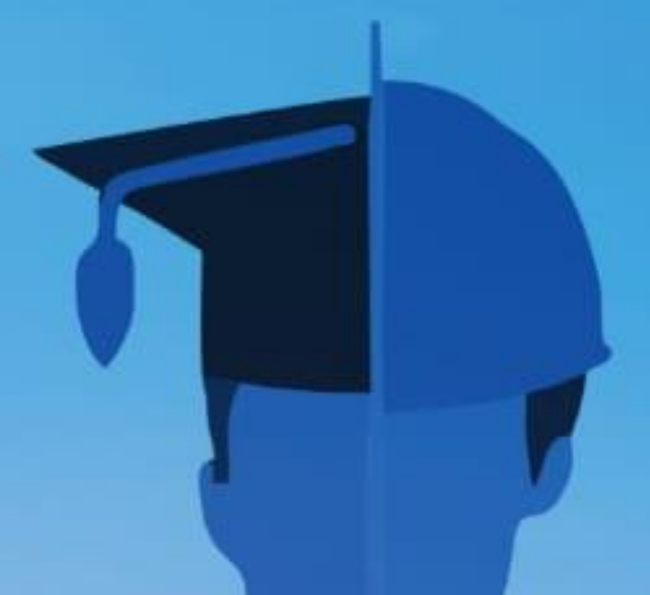

Laila Meilivandrie Indah Wardani, Ph. D

Rahmat Dwi Syaputra.S.Psi Nayang Safira Kartikawati. S. Psi Dyah Ayu Sekarini. S. Psi 


\section{I'M MISMATCH, BUT I'M WELL-BEING: EMPLOYEE WELL-BEING, JOB CRAFTING, DAN PSYCHOLOGICAL EMPOWERMENT}

Laila Meiliyandrie Indah Wardani, Ph. D

Rahmat Dwi Syaputra, S. Psi

Mayang Safira Kartikawati, S. Psi

Dyah Ayu Sekarini, S. Psi
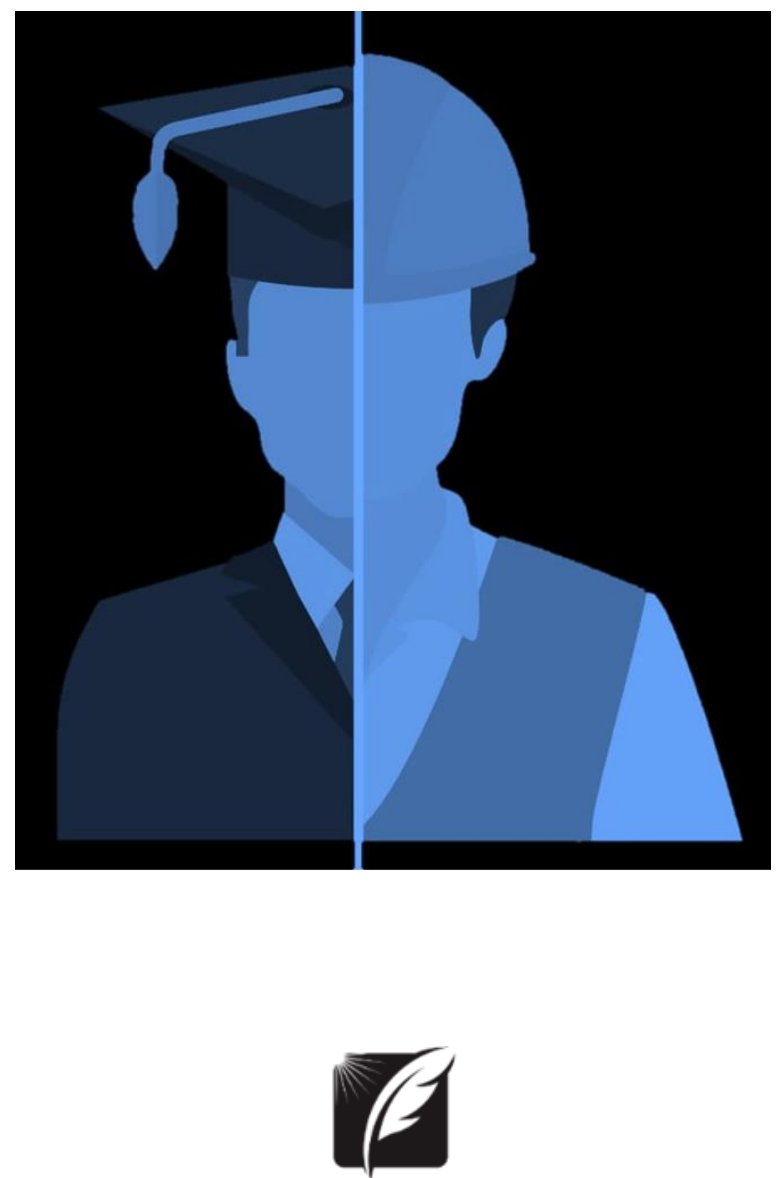

penapersada

PENERBIT CV. PENA PERSADA 


\title{
I'M MISMATCH, BUT I'M WELL-BEING: \\ EMPLOYEE WELL-BEING, JOB CRAFTING, DAN PSYCHOLOGICAL EMPOWERMENT
}

\section{Penulis:}

Laila Meiliyandrie Indah Wardani, Ph. D.

Rahmat Dwi Syaputra, S. Psi

Mayang Safira Kartikawati, S. Psi

Dyah Ayu Sekarini, S. Psi

$$
\text { ISBN : 978-623-315-299-0 }
$$

\author{
Editor: \\ Wiwit Kurniawan \\ Amrizal \\ Design Cover : \\ Retnani Nur Briliant \\ Layout : \\ Nisa Falahia \\ Penerbit CV. Pena Persada \\ Redaksi : \\ Jawa Tengah \\ Anggota IKAPI \\ All right reserved \\ Cetakan pertama : 2021
}

Jl. Gerilya No. 292 Purwokerto Selatan, Kab. Banyumas

Email : penerbit.penapersada@gmail.com

Website : penapersada.com Phone : (0281) 7771388

Hak Cipta dilindungi oleh undang-undang. Dilarang memperbanyak karya tulis ini dalam bentuk apa pun tanpa izin penerbit 


\section{KATA PENGANTAR}

Puji syukur saya panjatkan kepada Tuhan Yang Maha Esa, karena atas berkat dan rahmat-Nya, saya dapat menyelesaikan buku ini. Penulisan buku merupakan buah karya dari pemikiran penulis yang diberi judul "I'm mismatch, but I'm well-being: Employee Well-being, Job Crafting, dan Psychological Empowerment". Penulis menyadari bahwa tanpa bantuan dan bimbingan dari berbagai pihak sangatlah sulit bagi saya untuk menyelesaikan karya ini. Oleh karena itu, saya mengucapkan banyak terima kasih pada semua pihak yang telah membantu penyusunan buku ini. Sehingga buku ini bisa hadir di hadapan pembaca.

I'm mismatch, but I'm well-being: Employee Well-being, Job Crafting, dan Psychological Empowerment memiliki keterkaitan. Buku ini menunjukkan bahwa Psychological Empowerment berperan menjadi mediator hubungan antara Job Crafting dan Employee Wellbeing. Meskipun, tanpa adanya peran Psychological Empowerment sebagai mediator, Job Crafting, dan Employee Well-being memiliki hubungan yang positif dan signifikan. Namun, efek Job Crafting pada Employee Well-being akan lebih kuat apabila melalui Psychological Empowerment terlebih dahulu.

Penulis menyadari bahwa buku ini masih jauh dari kesempurnaan. Oleh karena itu kritik dan saran yang membangun sangat dibutuhkan guna penyempurnaan buku ini. Akhir kata saya berharap Tuhan Yang Maha Esa berkenan membalas segala kebaikan semua pihak yang telah membantu. Semoga buku ini akan membawa manfaat bagi kita semua. 


\section{DAFTAR ISI}

I'M MISMATCH, BUT I'M WELL-BEING: Employee Wellbeing, Job Crafting, dan Psychological Empowerment pada karyawan

KATA PENGANTAR iii

DAFTAR ISI iv

BAB I PENDAHULUAN

A. Persoalan Ketenagakerjaan di Indonesia .......................... 1

B. Kesejahteraan Karyawan .................................................... 3

BAB II EMPLOYEE WELL-BEING

A. Pengertian Employee Well-being ......................................... 8

B. Dimensi Employee Well-being .............................................. 9

C. Faktor-faktor yang Mempengaruhi Employee

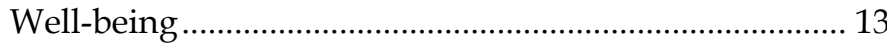

D. Implikasi Employee Well-being ............................................. 14

BAB III JOB CRAFTING

A. Pengertian Job Crafting......................................................... 16

B. Dimensi Job Crafting ............................................................ 16

C. Faktor-faktor yang Mempengaruhi Job Crafting .............. 18

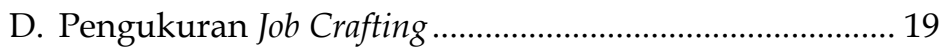

E. Implikasi Job Crafting .......................................................... 19

BAB IV PSYCHOLOGICAL EMPOWERMENT

A. Pengertian Psychological Empowerment ............................. 21

B. Dimensi Psychological Empowerment .................................. 22

C. Faktor-faktor yang Mempengaruhi

Psychological Empowerment ................................................ 24

D. Pengukuran Psychological Empowerment ........................... 24

E. Impilkasi Psychological Empowerment ................................ 25

BAB V GAMBARAN UMUM PEKERJA HORIZONTAL EDUCATION MISMATCH
A. Jenis Kelamin 26

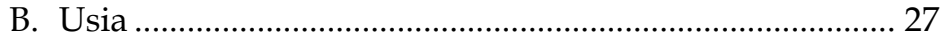

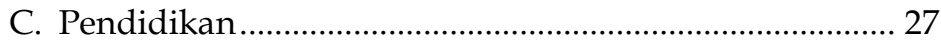
D. Status Pernikahan ............................................................ 28

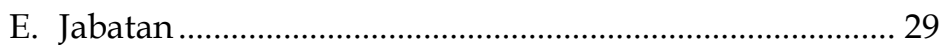

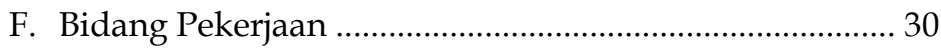


BAB VI DESKRIPSI EMPLOYEE WELL-BEING, JOB CRAFTING DAN PSYCHOLOGICAL EMPOWERMENT

A. Berbagai Kajian tentang Employee Well-being, Job Crafting dan Psychological Empowerment ..................... 34

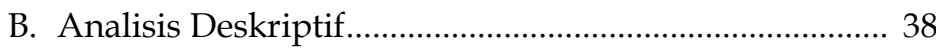

1. Employee Well-being ....................................................... 40

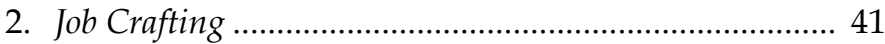

3. Psychological Empowerment ............................................ 41

C. Analisis Asosiatif para Employee Well-being, Job Crafting dan Psychological Empowerment ..................... 42

1. Analisa Regresi Mediasi .............................................. 42

2. Persamaan Regresi Berganda........................................ 46

3. Matrix Correlation Antar Dimensi ............................... 47

D. Uji Beda pada Employee Well-being, Job Crafting dan Psychological Empowerment.......................................... 52

1. Independent T-Test .................................................... 52

2. ANOVA One way......................................................... 53

E. Hubungan antara Employee Well-being, Job Crafting Dan Psychological Empowerment ........................ 57

BAB VII KESIMPULAN DAN SARAN....................................... 66

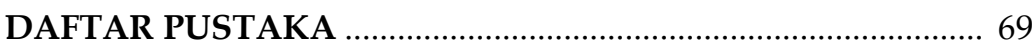




\section{I'M MISMATCH, BUT I'M WELL-BEING:}

\section{EMPLOYEE WELL-BEING, JOB CRAFTING, DAN}

PSYCHOLOGICAL EMPOWERMENT

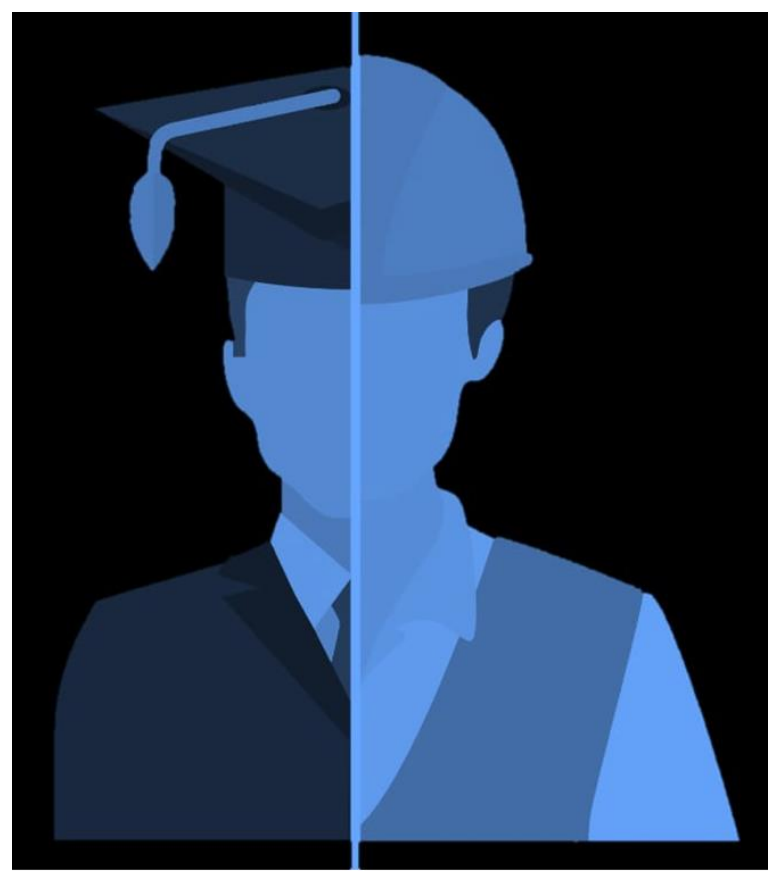




\section{BAB I \\ PENDAHULUAN}

\section{A. Persoalan Ketenagakerjaan di Indonesia}

Jika membahas permasalahan ketenagakerjaan di negara ini (Indonesia), yang terbesit pertama kali dalam pikiran adalah kata pengangguran. Data yang dikeluarkan Badan Pusat Statistik (2020) pada bulan februari lalu, menjelaskan ada sekitar 6,88 juta pengangguran yang ada di Indonesia, jumlah ini bertambah sebanyak 60 ribu orang jika dibandingkan dengan jumlah pengangguran pada bulan februari 2019 yang lalu. Pengangguran yang bertambah setiap tahunnya disebabkan oleh ketidakseimbangan antara lapangan pekerjaan yang tersedia terhadap jumlah orang yang membutuhkan pekerjaan dan ditambah lagi adanya kekurangan pada pelamar terkait dengan keahlian yang dimiliki terhadap keahlian yang menjadi kriteria dari pembuka lapangan pekerjaan (Franita, 2016). Lalu, hal tersebut membuat kompetisi dalam mencari pekerjaan semakin tinggi diantara sesama pencari kerja. Hingga akhirnya, pekerjaan apapun dilakukan demi tidak menjadi seorang pengangguran walaupun pekerjaan yang diambil tidak sesuai dengan pendidikan yang diraih, hal ini biasa disebut dengan education mismatch (Suryono \& Pitoyo, 2013).

Education mismatch di Indonesia khususnya di Jakarta sendiri telah menjadi suatu hal yang wajar di kalangan masyarakat. Seperti telah diketahui, Jakarta menjadi kota terbesar kedua di Asia Tenggara sebagai kota metropolitan, yang mana artinya menjadi kota dengan pusat bisnis, pemerintahan, gedung pencakar langit, dan lain-lain di dalamnya (Silitonga, 2010). Lalu, diketahui pula perputaran uang sebanyak $70 \%$ di negara ini berada di Jakarta (detikFinance, 2013). Hal ini membuat banyak orang datang ke Jakarta untuk mengadu nasib mencari pekerjaan. Pekerjaan apa 
pun dilakoni sebagai penyambung hidup untuk diri dan keluarga.

Oleh karena itu, kita menemukan sebagian besar di lingkungan keluarga, tetangga ataupun di sekeliling kita, beberapa orang mempunyai pekerjaan yang tidak sesuai dengan pendidikan yang dijalaninya, layaknya seorang sarjana teknik bekerja sebagai pegawai bank, sarjana kesehatan masyarakat bekerja sebagai montir, ataupun sarjana psikologi yang beralih menjadi seorang petani hidroponik seperti Faris yang viral 2 tahun yang lalu karena telah sukses menjadi tukang sayur hidroponik di daerahnya, Yogyakarta (CapCapung, 2017).

Menteri Tenaga Kerja, Muhammad Hanif Dhakiri menyebutkan terdapat $63 \%$ dari jumlah angkatan kerja di Indonesia memiliki latar belakang pendidikan yang berbeda dengan pekerjaan yang ditekuni sekarang, yang mana artinya ada tiga atau empat dari sepuluh orang yang hanya match dengan pekerjaannya sekarang (Rahmawati, 2017). Education mismatch sendiri, sebenarnya dibedakan menjadi dua, horizontal education mismatch dan vertical education mismatch, dalam penelitian ini hanya berfokus pada horizontal education mismatch, yaitu ketidakesesuaian antara tipe pendidikan yang dimiliki dan pekerjaan yang ditekuni sekarang (Robts, 2007).

Masalah terkait education mismatch di Indonesia yang telah lumrah di kalangan pencari lapangan kerja, ternyata juga menjadi persoalan bagi penyedia lapangan kerja. Pedulla (2016, dalam Wardani \& Fatimah, 2020) menjelaskan bahwa keadaan seperti ini membuat perusahaan-perusahaan penyedia lapangan pekerjaan, akhirnya bergantung kepada pasar tenaga kerja yang tidak sesuai dengan jenis kebutuhannya untuk mengisi tempat yang dibutuhkan. Dengan keadaan yang seperti ini, menjadikan karyawan yang mengalami horizontal education mismatch mau tidak mau mengeluarkan usaha yang lebih dari karyawan biasanya terhadap pekerjaan yang dilakukan, mereka dituntut untuk mempelajari hal-hal yang tidak menjadi suatu kebiasaan sebelumnya, mulai dari 
kompetensi, kemampuan, keterampilan, budaya, dan hal lainnya di tempat kerja yang sekarang (Wardani \& Fatimah, 2020).

Kemudian, perlu dipahami bersama, peristiwa ini tidak berjalan dengan baik begitu saja, pastinya akan ada dampak yang terjadi ketika seorang karyawan memilih bekerja tidak sesuai dengan bidang pendidikan yang diambil. Walaupun Wardani, Wulandari, Triasti, dan Sombuling (2020) mengatakan bahwa pekerja yang mengalami mismatch merasakan engagement terhadap pekerjaannya. Mismatch yang terjadi di kalangan ketenagakerjaan ini berdampak pada tingkat kepuasan kerja karyawan yang menjadi rendah, meningkatnya turnover di dalam perusahaan, serta turut menyebabkan pendapatan rendah pada karyawan tersebut (Bender \& Roche, 2013). Lebih jauh lagi, hal ini akan berdampak pada karyawan yang dapat mengalami stres kerja, ini dapat terjadi dikarenakan karyawan tersebut pastinya akan menghadapi hal-hal yang berbeda dari sebelumnya serta tuntutan yang belum pernah dirasakan atau menjadi pengalaman pertama dalam hal ini (Prabowo, 2014). Beban karyawan dalam menyesuaikan hal tersebutlah yang kemudian menjadi potensi menyebabkan bertambah buruknya kesehatan, peforma kerja, dan kesejahteraan karyawan atau disebut juga Employee Well-being (Anwarsyah, Salendu \& Radikun, 2012).

\section{B. Kesejahteraan Karyawan}

Employee Well-being sendiri merupakan gambaran keadaan karyawan dalam bekerja yang dilihat bukan hanya dari sudut pandang dirinya sendiri mengenai kepuasan pekerjaan yang dirasakan ataupun kelelahan yang didapatkan secara emosional, tetapi juga menggambarkan kesejahteraan karyawan tersebut secara menyeluruh, seperti aspek fisik, psikologis, maupun pribadi individu itu sendiri (Zheng, Zhu, Zhao dan Chi, 2015). Page dan Vella-Brodwick (2009) lebih lanjut menyatakan bahwa, terdapat tiga dimensi dalam menjelaskan terkait dengan Employee Well-being, yaitu subjective 
well-being, workplace well-being, dan psychological well-being. Seperti dijelaskan sebelumnya, untuk melihat kesejahteraan secara keseluruhan, harus digambarkan melalui kualitas kesejahteraan individu itu sendiri, kesejahteraan pada tempat kerjanya, serta kesejahteraan yang dilihat pada aspek psikologis individu yang bersangkutan. Selanjutnya, Employee Well-being menjadi peran penting dalam suatu perusahaan atau organisasi, hal ini dikarenakan Employee Well-being menjadi hal krusial dalam meningkatkan performa kinerja karyawan (Russel, 2008), ketika seseorang karyawan merasakan Employee Well-being yang tinggi, hal ini juga turut meningkatkan kinerja karyawan tersebut dalam bekerja dan juga Employee Well-being yang turut mempengaruhi turn over pada perusahaan tersebut, kepuasaan kerja, dan ketidakhadiran kerja (Chou, Chu, Yeh, \& Chen, 2014).

Ketika suatu perusahaan atau organisasi telah mengetahui bahwa cara meningkatkan performa kinerja karyawan adalah dengan melalui peningkatan Employee Wellbeing. Oleh sebab itu, perusahaan harus melakukan tindakan dalam upaya menjaga kesejahteraan karyawannya agar terus meningkat. Ada hal yang dapat mempengaruhi Employee Wellbeing, yaitu kemampuan yang dimiliki seorang karyawan dalam melakukan perubahan atas pekerjaannya entah itu dari segi fisik atau kognitif yang diseimbangkan antara karakteristik pekerjaan dan karakteristik pribadinya, ini yang disebut dengan konsep Job Crafting (Elbanawey, 2018). Berg, Dutton, dan Wrzesniewski (2008) menjelaskan bahwa ada tiga dimensi di dalam Job Crafting, yaitu increasing structural job resources yang mana dalam hal ini mengacu pada karyawan yang aktif melakukan pengembangan diri terhadap dirinya berupa kemampuan dan pengetahuan terbaru terkait dengan pekerjaannya (Tims, Bakker, \& Derks, 2012). Increasing social job resources yang di dalamnya terkait dengan penilaian yang diberikan oleh rekan kerja atau pimpinan atasan berupa saran dan kritik sebagai pembelajaran diri, dukungan sosial terbentuk secara harmonis, serta adanya pembinaan 
pengawasan (Tims, Bakker, \& Derks, 2012), dan terakhir increasing challenging job demand, yang mana hal ini menjelaskan bahwa tuntutan pekerjaan yang lebih menantang akan membuat karyawan bertindak melakukan pengembangan terhadap pengetahuan dan keterampilan mereka (Wardani \& Wahyuni, 2020).

Pada akhirnya, kesejahteraan seorang karyawan agar terus terjaga seiring dengan kemampuan seseorang dalam mengontrol lingkungan pekerjaannya agar sesuai dengan karakteristik pribadinya (Job Crafting) yang kian meningkat. Kemudian, peneliti menyadari bahwa ternyata selain dari peningkatan Job Crafting yang dimiliki seorang karyawan akan turut meningkatkan kesejahteraannya, ada hal lainnya yang juga dapat mempengaruhi Employee Well-being.

Seperti kita tahu, kesejahteraan yang dimiliki karyawan akan mengarahkan pada individu tersebut membangun fungsi positif pada dirinya. Fungsi positif ini menjadikan dirinya mampu untuk menetapkan tujuan dan arti pada hidupnya, dapat memiliki kontrol dalam lingkungan pekerjaannya, serta dapat membangun hubungan yang harmonis dengan orang di sekitarnya (Wardani \& Amaliah, 2020). Keadaan seperti ini merupakan wujud dari konstruksi motivasional seorang karyawan yang memahami betul kompetensi yang dimilikinya sehingga karyawan tersebut secara sadar meningkatkan kapabilitasnya dan menunjukkan kebutuhan kekuatan ataupun autonomi, ini yang disebut dengan Psychological Empowerment (Wardani \& Amaliah, 2020).

Kemudian, penulis menyadari bahwa sebenarnya Psychological Empowerment yang dimiliki seorang karyawan dalam mempengaruhi Employee Well-being, ternyata didasarkan pada representasi perilaku proaktif karyawan yang memiliki Job Crafting. Pada penelitian yang dilakukan oleh Siddiqui, Raza, dan Imran (2017), dijelaskan bahwa Job Crafting memiliki pengaruh yang positif terhadap Psychological Empowerment.

Selanjutnya, Psychological Empowerment sendiri sebagai intervensi yang dilakukan oleh atasan kepada bawahan, yang 
mana dalam hal ini atasan memberikan tanggung jawab kepada bawahan atau pekerja dalam memikul suatu pekerjaan yang harus diselesaikan dengan baik dan hasil dari merasa diperdayakan oleh atasan ini akan meningkatkan motivasi dan kepercayaan diri dalam bekerja (Wardani \& Amaliah, 2020). Sebagai tambahan menurut Wardani dan Noviyani (2020) pekerja yang puas dengan lingkungan kerjanya akan berdampak pada kepercayaan dirinya sehingga dapat fokus pada tujuan dan tugasnya.

Psychological Empowerment memiliki peran penting dalam ketenagakerjaan terkhusus pada para pekerja. Kita mengetahui di kemudian hari akan terjadi perubahan-perubahan dalam pekerjaan yang dijalani akibat persaingan global, untuk menghadapi hal tersebut para pekerja dituntut untuk mampu menanggulangi permasalahan tersebut dengan cara meningkatkan Psychological Empowerment. Para pekerja dituntut untuk menanamkan rasa yakin dalam menyelesaikan semua tugas atau tuntutan kerja yang didapatkan, rasa yakin ini didapatkan bukan tanpa sebab, rasa yakin ini timbul akibat pekerja yang mampu memahami peran pekerjaannya dan mengambil makna dari pekerjaan tersebut (Spreitzer, 1995). Lalu, rasa yakin yang timbul akibat kepercayaan atas kemampuan dan keterampilan yang memang dibutuhkan serta rasa yakin yang timbul karena terus mengembangkan diri dengan cara mengasah keterampilan, kemampuan, dan pengetahuan yang dibutuhkan dalam menunjang pekerjaan (Spreitzer, 1995). Rasa yakin inilah yang kemudian mampu menghindarkan pekerja pada tekanan-tekanan kerja yang berlebihan.

Dengan fenomena yang telah dijelaskan di atas, penulis menyadari bahwa Employee Well-being, Job Crafting, dan Psychological Empowerment memiliki keterkaitan. Penelitian sebelumnya hanya membahas terkait dengan hubungan antara Job Crafting dan Employee Well-being saja (Wardani \& Amaliah, 2020) tetapi penulis melihat bahwa ada satu variabel lagi yang dapat menjadi peran sebagai mediator antara Job Crafting dan 
Employee Well-being, yaitu Psychological Empowerment. Variabel mediator sendiri merupakan variabel yang mempunyai keterkaitan terhadap variabel independen dan variabel dependen (Sari, 2016). Dalam hal ini dijelaskan bahwa Psychological Empowerment menjadi faktor dalam mempengaruhi kondisi Employee Well-being (Wardani \& Amaliah, 2020) dan Psychological Empowerment sendiri dipengaruhi oleh Job Crafting (Aisyah, 2019).

Kemudian, ditambah dengan adanya karyawan yang mengalami horizontal education mismatch, kompetensi pendidikan yang dimiliki berbeda dengan bidang pekerjaan yang dilakukan membuat penulis berpikir apakah Job Crafting dan Employee Well-being akan tetap saling berhubungan positif seperti penelitian sebelumnya, begitu juga dengan Job Crafting dan Psychological Empowerment serta Psychological Empowerment dan Employee Well-being pada karyawan yang mengalami horizontal education mismatch. Selain itu juga, apakah Psychological Empowerment sebagai mediator mampu meningkatkan Employee Well-being secara tidak langsung melalui career competencies. Oleh karena itu, penulis membuat penelitian ini yang berjudul "Peran Psychological Empowerment sebagai Mediator dari Hubungan antara Job Crafting dan Employee Well-being terhadap Karyawan yang Mengalami Horizontal Education Mismatch". 


\section{BAB II \\ EMPLOYEE WELL-BEING}

\section{A. Pengertian Employee Well-being}

Employee Well-being sendiri merupakan gambaran keadaan karyawan dalam bekerja yang dilihat bukan hanya dari sudut pandang dirinya sendiri mengenai kepuasan pekerjaan yang dirasakan ataupun kelelahan yang didapatkan secara emosional, tetapi juga menggambarkan kesejahteraan karyawan tersebut secara menyeluruh, seperti aspek fisik, psikologis, maupun pribadi individu itu sendiri (Zheng, Zhu, Zhao dan Chi, 2015). Selain itu, menurut Mitchell (2018), Employee Well-being merupakan keadaan seorang karyawan dalam pekerjaannya yang memperlihatkan kesehatan fisik, mental, suasana hati, dan emosi yang positif seperti bahagia, nyaman, sehat, aman, serta terjamin. Dan terakhir, ada juga definisi Employee Well-being menurut Wright, dkk (dalam Rizky \& Sadida, 2019) yang mengatakan bahwa hal tersebut ialah kehidupan karyawan selama bekerja yang dapat dijelaskan dari seluruh aspek pekerjaannya, yang meliputi pandangannya terhadap kebahagiaan yang dirasakan ataupun keseimbangan yang didapatkan antara emosi positif dan emosi negatif.

Dari ketiga definisi Employee Well-being menurut para ahli di atas, dapat disimpulkan bahwa Employee Well-being merupakan keadaan seorang karyawan dalam pekerjaannya, yang dilihat dari pandangannya terhadap kebahagiaan yang dirasakan ataupun keseimbangan antara emosi positif dan negatif yang didapatkan, serta gambaran kesejahteraan yang dilihat secara menyeluruh terhadap aspek fisik, psikologis ataupun pribadi individu. 


\section{B. Dimensi Employee Well-being}

Pada Employee Well-being terdapat tiga dimensi yang dikemukakan oleh Zheng, Zhu, Zhao dan Chi (2015), sebagai berikut:

\section{Life well-being (LWB)}

Life well-being merupakan pandangan seseorang terhadap pengalaman yang dialami semasa hidupnya dan istilah life well-being ini diartikan sebagai gambaran terkait dengan makna yang dimaksud atau juga bisa dikatakan sebagai persepsi seseorang tentang apa yang telah dialaminya meliputi evaluasi kognitif dan afeksi yang mana hal ini menjelaskan terkait dengan kesejahteraan psikologis yang dimiliki (Wardani \& Amaliah, 2020). Aspek pada life well-being sendiri mencakup personal and family care, hal ini merepresentasikan emosi pribadi seorang karyawan dan family member yang mana hal ini mengenai masalah kehidupan keluarga (Zheng, Zhu, Zhao dan Chi, 2015).

2. Workplace well-being (WWB)

Workplace well-being diartikan sebagai gambaran keadaan seorang karyawan yang menunjukkan perasaan sejahtera dari hasil pekerjaan yang mereka lakukan meliputi perasaan pekerja secara umum atau disebut juga core effect dan perasaan pekerja melalui nilai instrinsik maupun ekstrinsik atau disebut work value. Core effect sendiri diartikan sebagai perasaan pekerja secara umum yang meliputi rasa nyaman dan tidak nyaman bersatu dan juga hal yang mempengaruhi tingkah laku manusia, yaitu passion (Page, 2005).

Russel (2008, dalam Wardani dan Amaliah, 2020) menjelaskan bahwa refleks, persepsi, kognisi, serta perilaku individu yang dipengaruhi oleh core affect emosi, suasana hati, dan keadaan emosi pada diri seseorang berkaitan dengan keadaan internal ataupun eksternal. Sedangkan, 
perasaan pekerja dari nilai pekerjaannya atau work value merupakan hal penting bagi seseorang dalam melakukan pekerjaanya dengan bahagia, dikarenakan work value sebagai nilai intrinsik dan ekstrinsik berisikan derajat harga, kepentingan, dan semua hal yang terkait dengan apa yang menjadikan kesenangan seseorang di tempat kerjanya (Page, 2005).

3. Psychological well-being (PWB)

Ryff dan Keyes (1995) mendefinisikan psychological well-being atau kesejahteraan psikologis sebagai keadaan seseorang yang dinilai secara aktif oleh dirinya pribadi atas pengalaman-pengalaman hidupnya. Schultz (dalam Ramadhani, Djunaedi, dan Sismiati, 2016) mengatakan bahwa psychological well-being sebagai fungsi positif seseorang yang mana arah atau tujuan yang diusahakan untuk dicapai oleh individu yang sehat. Ryff (1989, dalam Halim \& Dariyo, 2016) menyatakan bahwa psychological wellbeing yang menjadi terpenting untuk menjadi perhatian adalah memiliki penerimaan diri, hubungan positif dengan orang lain, otonomi, adanya kemampuan untuk menguasai lingkungan, memiliki tujuan dan arti hidup dan memiliki rasa pertumbuhan serta pengembangan diri secara berkelanjutan.

Ada enam aspek dalam psychological well-being yang disampaikan oleh Ryff (1989, dalam Halim \& Dariyo, 2016), antara lain:

a. Penerimaan diri (Self-Acceptance)

Penerimaan diri merupakan representatif dari keadaan kesejahteraan seseorang, yang mana dalam hal ini penerimaan diri menunjukkan sikap positif dalam diri seseorang tersebut termasuk kedewasaan yang dirasakan dalam melewati semua kehidupan. Seseorang yang memiliki aspek penerimaan diri yang tinggi 
digambarkan menjadi seseorang yang mempunyai sikap positif terhadap dirinya serta kehidupan yang dilalui dan mempunyai sikap dalam menerima kehidupan, entah itu baik ataupun buruk.

b. Hubungan positif dengan orang lain (Positive Relationship with Others)

Dalam hal ini, menggambarkan bagaimana kemudian seseorang seharusnya bertindak dalam berhubungan dengan orang lain. Ketika seseorang akhirnya mampu memiliki hubungan positif orang lain, mereka akan menunjukkan keharmonisan terhadap sesama, membangun rasa percaya terhadap orang lain, memiliki rasa empati dan saling mencintai terhadap satu sama lain. Lain halnya, ketika seseorang sulit memiliki hubungan positif dengan orang lain, mereka menunjukkan rasa ketidakpercayaan terhadap orang lain, merasa sulit untuk menjadi hangat serta terbuka, frustasi, dan menolak untuk menyesuaikan karakteristik diri dalam menjaga hubungan yang harmonis dengan orang lain.

\section{c. Otonomi (Autonomy)}

Yang dimaksud otonomi adalah ketika seseorang mampu mengontrol tingkah laku pribadi ke arah menjadi seseorang yang mampu untuk mandiri dan mampu untuk menghadapi tekanan sosial yang didapatkan dalam kehidupan serta menjadi pribadi yang dapat mengevaluasi diri terhadap apa yang telah dilalui. Jika seseorang memiliki otonomi diri yang rendah, mereka akan menunjukkan sikap bergantung terhadap penilaian orang lain, entah dalam hal membuat keputusan, bagaimana menghadapi suatu permasalahan sosial, serta bagaimana bersikap melakukan evaluasi terhadap diri sendiri, semunya bergantung pada pengharapan oleh orang lain. 
d. Penguasaan Lingkungan (Environmental Mastery)

Penguasaan lingkungan atau environmental mastery merepresentasikan keadaan seseorang dalam menciptakan lingkungan sesuai dengan kondisi fisiknya berdasarkan taraf kedewasaan yang dimiliki meliputi aktivitas mental dan fisik. Ketika nilai seseorang pada penguasaan lingkungan tinggi, ini menggambarkan seseorang mampu menyesuaikan lingkungan yang ada terhadap karakteristik diri dan akhirnya mampu membuat kesempatan-kesempatan secara efektif dalam apa yang dilakukan. Sedangkan, ketika nilainya rendah, ini menggambarkan seseorang yang tidak mempunyai kontrol terhadap lingkungannya sehingga sulit untuknya mengontrol aktivitas-aktivitas agar sesuai dengan karakteristik pribadinya.

e. Tujuan dalam hidup (Purpose in Life)

Tujuan dalam hidup atau purpose in life merepresentasikan keadaan seseorang dalam menjalani kehidupannya. Ketika nilai seseorang pada tujuan dalam hidupnya tinggi, ini menggambarkan seseorang tersebut memahami makna dalam semasa hidupnya entah itu sekarang atau masa lampau. Sedangkan, ketika seseorang memiliki nilai rendah, akan menunjukkan gambaran kehidupan yang kurang memaknai arti hidup yang dijalani dari masa lampau hingga masa sekarang dan tidak terlihat jelas hidup akan dibawa ke mana.

f. Pertumbuhan Pribadi (Personal Growth)

Ryff (1995) menjelaskan bahwa pertumbuhan pribadi atau personal growth merepresentasikan keadaan seseorang yang mana hal ini terkait dengan pengembangan potensi diri serta bagaimana 
memanfaatkan apa yang menjadi potensi. Ketika nilai pertumbuhan diri dalam diri seseorang tinggi, ini menggambarkan seseorang yang mampu terbuka dalam pengalaman baru, melihat diri yang mempunyai kemajuan dari masa ke masa dan melihat diri yang terus mengembangkan potensi yang ada. Sedangkan, ketika nilai seseorang rendah, ini menggambarkan seseorang yang merasakan ketidakmampuan dalam menjalani hidup karena tidak dapat mengembangkan potensi yang ada dalam diri sehingga kejenuhan pun dirasakan.

\section{Faktor-faktor yang Mempengaruhi Employee Well-being}

Terdapat empat faktor yang dapat mempengaruhi Employee Well-being, sebagai berikut (Ananda, 2010):

1. Gaji

Gaji merupakan upah yang diterima oleh para karyawan atau tenaga kerja sebanyak yang uang yang telah disepakati sebagai hasil dari apa yang telah dikerjakan dalam waktu tertentu, entah sehari, seminggu, ataupun sebulan (Subianto, 2016). Gaji memiliki pengaruh yang signifikan terhadap kinerja, karena jumlah gaji yang diberikan tepat akan memotivasi diri untuk meningkatkan kinerja yang ada.

2. Insentif

Suatu penghargaan yang diberikan kepada para karyawan negeri atau swasta dalam bentuk material sebagai langkah dalam menstimulasi motivasi kerja yang lebih tinggi lagi sehingga dapat melakukan tugas dengan sebaikbaiknya (Subianto, 2016). 